\title{
CHRONIC ARTHRITIS AFTER RECURRENT RHEUMATIC FEVER
}

\author{
BY
}

\author{
A. E. THOMAS* \\ Royal Infirmary, Sheffield
}

(RECEIVED FOR PUBLICATION OCTOBER 4, 1954)

During the late 19th century the term "rheumatic fever" was applied to any case of acute febrile polyarthritis. In the past 50 years much evidence has been produced to support the view that rheumatic fever represents an abnormal tissue reaction to the products of Group A streptococcal infections (Poynton and Paine, 1913; Todd, 1932; Coburn and Pauli, 1935; Rothbard and others, 1948; Swift, 1952).

It is now recognized that rheumatoid disease may present as an acute febrile polyarthritis, but that this disease is not specially associated with streptococcal infection. Furthermore, in rheumatoid disease, there is a serum factor which forms the basis of the she $\geq p$ cell agglutination test for this condition (Rose and others, 1948). This test gives negative results in patients with rheumatic fever. The older definitions of rheumatic fever as acute rheumatism and of rheumatoid disease as chronic rheumatism are no longer satisfactory, and it becomes desirable to know whether the rheumatic fever process may on occasion give rise to chronic joint disease.

Between 20 and 50 per cent. of patients with rheumatic fever eventually develop chronic heart disease (Edström, 1935; Coombs, 1924; Arnsø and others, 1951) and nearly all of them manifest one or more valvular lesions. The mitral valve is affected in 85 per cent., the aortic in 44 per cent., the tricuspid in 10 per cent., and the pulmonary in 1 or 2 per cent. (Cabot, 1926). It is generally agreed that the presence of a mitral lesion implies the existence of chronic heart disease resulting from a previous active rheumatic fever process. This observation is of some importance, as only 55 per cent. of cases of mitral stenosis give a history of the original attack (Parkinson and Hartley, 1946). As rheumatic fever commonly causes permanent changes in the heart, it is surprising that the present

* This work was carried out at the Rheumatism Research Centre, Manchester Royal Infirmary. view of the complete reversibility of acute rheumatic polyarthritis is so widely accepted. One would expect a disease which attacks the cardiovascular and locomotor systems with equal frequency in its acute phase to produce permanent structural changes in both.

Follow-up studies of patients who had been treated for rheumatic fever have been carried out by a number of Scandinavian authors and some of them have reported chronic arthritis in 20 to 30 per cent. of their cases (Jespersen, 1941; Edström, 1935; Arnsø and others, 1951). Ehlertsen (1942), however, in a similar study was unable to confirm these findings. Unfortunately, these reports lack clinical detail and the incidence of chronic arthritis which they give is probably too high, as they all relate to a period when the term rheumatic fever was applied to any acute febrile polyarthritis.

Jaccoud (1869) gave the first detailed clinical description of chronic arthritis after rheumatic fever. This patient, a youth of 19 , suffered from four attacks in which the hands and feet escaped, but in the course of which he developed aortic stenosis and incompetence. In two subsequent attacks deformities of the hands and feet, at first correctable but later permanent, appeared. There was marked ulnar deviation of the fingers and hyperextension of the middle on the proximal phalanx in the case of the second, third and fourth digits, unaccompanied by clinical evidence of bone destruction.

As the changes were situated chiefly in the joint capsules, he named the condition chronic fibrous rheumatism. Sporadic reports of similar cases have appeared in the literature, and Bywaters (1950) gives an excellent review of them. In addition he cites two cases of his own and in a study of autopsy material found joint changes which were possibly of the Jaccoud type in three out of five subjects with rheumatic heart disease. 
Involvement of the spine after rheumatic fever has been described from time to time in the literature. Poynton and Paine (1913) stated that the disease "may attack large as well as small joints, and may even in the young sometimes produce a very chronic spondylitis deformans". They considered that the likelihood of developing chronic arthritis increased with each succeeding attack. Krebs and Wurm (1938) were of the opinion that cardiac involvement was most frequently seen in those cases of spondylitis which follow rheumatic fever. The only patient with rheumatic heart disease among a small series of cases of ankylosing spondylitis described by Edström (1940) had suffered repeated attacks of rheumatic fever. In this case the $x$-ray changes in the spine and sacro-iliac joints were not typical of ankylosing spondylitis, and the condition underwent remission during treatment with salicylates. A somewhat similar case with atypical $x$-ray changes was mentioned by Herrick and Tyson (1941). Engleman and others (1951) found no peripheral joint changes among 137 veterans who had suffered from rheumatic fever during the second world war, but the existence of "rheumatoid spondylitis" in three of these patients was discovered by routine radiography of their sacro-iliac joints.

In a study of 352 cases of ankylosing spondylitis, Bernstein and Broch (1949) found valvular lesions in ten. They concluded that, in such cases, acute rheumatism should be regarded "as being part of the essential pathological picture presented by the patients". Recently the clinical and radiological features of ankylosing spondylitis have been more clearly defined (Mowbray and others, 1949; Hart and others, 1949), and Sharp and Easson (1954) have shown that only typical cases respond to radiotherapy. These authors suggest that atypical cases may result from involvement of the spine in other disease processes.

Bauer and others (1951) reported that the incidence of aortic regurgitation as a solitary lesion was higher among patients with rheumatoid arthritis than among a comparable group with rheumatic heart disease, indicating in their view, that aortic involvement is a manifestation of rheumatoid arthritis. Spinal involvement was a constant feature, but 75 per cent. had peripheral joint disease as well. Finally, Young and Schwedel (1944), in an account of 38 autopsies in patients with chronic arthritis, found valvular lesions of rheumatic origin in 24 ; fourteen had suffered from repeated attacks of acute polyarthritis, and in 23 there was evidence of spinal involvement.

Thus, from a study of the literature, there appears to be some association between recurrent rheumatic fever, valvular heart lesions, and an unusual form of chronic arthritis of which spondylitis is a prominent $\square$ feature.

\section{Present Study}

Of all the patients who attended the Rheumatism Clinic at the Manchester Royal Infirmary between 1948 and 1953, 55 were recorded as having valvular disease of the heart, but only 28 of these were avail- $\stackrel{\varnothing}{\varnothing}$ able for re-examination, together with the details of $\approx$ one fatal case.

These patients were re-investigated, special attention being paid to incidence of attacks of rheumatic $\vec{\omega}$ fever, their relation to preceding infection and the effect of salicylates on the symptomatology and $\frac{0}{2}$ course of the disease. The character and pattern of $\overrightarrow{\vec{A}}$ joint involvement was noted, together with asso- $\vec{\omega}$ ciated findings such as vasospasm and sweating of i the extremities, tendon and subcutaneous nodules, $\mathcal{O}$ atrophy of the skin and muscles and lymphadeno- $\frac{\text { ? }}{2}$ pathy. All these cases had either a typical mitral $\vec{\Delta}$ presystolic or mid-diastolic murmur, or a to-and-fro $\mathbb{D}$ aortic murmur, or both, and in most of them con- $\frac{\mathbb{D}}{\mathbb{D}}$ firmatory radiological and electrocardiographic findings were available.

The following laboratory tests were carried out in most cases: erythrocyte sedimentation rate (Westeg $\vec{\rho}$ gren with citrate anti-coagulant), differential sheer or cell agglutination test (D.A.T.) by the method Ball (1950), and antistreptolysin " $O$ " titrations (A.S.T.) (Todd, 1932).

$X$-ray studies were confined to the affected joints in those patients who on the clinical assessment $\stackrel{\mathbb{D}}{\mathbb{D}}$ appeared to be suffering from rheumatoid arthritis. $\overrightarrow{\vec{A}}$ In the remainder, films of the hands, feet, pelvis, with special views of the sacro-iliac joints, and the whole of the spine were obtained.

\section{Results}

The main findings in these 29 patients are summarized in Table I (opposite).

Rheumatoid arthritis was diagnosed in those patients who presented a symmetrical polyarthritis $ᄋ$ affecting the small joints of the hands and feet, $D$ characterized by tender soft tissue thickening and limitation of the affected joints with radiological $\bar{N}$ evidence of bone destruction as described by os Fletcher and Rowley (1952). The frequent finding $N$ of vaso spasm and excessive sweating of the extremi- ్․․ ties, lymphadenopathy, necrobiotic nodules, and 0 atrophic changes in muscle and skin supported this 6 diagnosis. Cases 1 to 13 and also Case 19 fulfilled most of these criteria. Aspirin in a dosage of $60 \mathrm{gr} . \stackrel{\oplus}{+}$ or more daily produced moderate relief of joint $\square$ 
TABLE I

MAIN FINDINGS IN 29 PATIENTS

\begin{tabular}{|c|c|c|c|c|c|c|c|c|c|c|c|c|c|}
\hline \multirow{2}{*}{$\begin{array}{l}\text { Case } \\
\text { No. }\end{array}$} & \multirow{2}{*}{ Sex } & \multirow{2}{*}{ Age } & \multirow{2}{*}{$\begin{array}{l}\text { Dura- } \\
\text { tion } \\
\text { (yrs) }\end{array}$} & \multirow{2}{*}{$\begin{array}{l}\text { No. of } \\
\text { Attacks } \\
\text { of } \\
\text { Rheu- } \\
\text { matic } \\
\text { Fever }\end{array}$} & \multirow{2}{*}{$\begin{array}{c}\text { Aspirin } \\
\text { Response }\end{array}$} & \multicolumn{2}{|c|}{ Peripheral Joints } & \multicolumn{2}{|c|}{ Central Joints } & \multirow{2}{*}{$\begin{array}{c}\text { Differ- } \\
\text { ential } \\
\text { Sheep Cell } \\
\text { Aggluti- } \\
\text { nation } \\
\text { Test }\end{array}$} & \multirow{2}{*}{$\begin{array}{l}\text { Erythro- } \\
\text { cyte } \\
\text { Sedimen- } \\
\text { tation } \\
\text { Rate }\end{array}$} & \multirow{2}{*}{$\begin{array}{l}\text { Anti- } \\
\text { streptolysin } \\
\text { Titration }\end{array}$} & \multirow{2}{*}{$\begin{array}{c}\text { Heart } \\
\text { Lesion }\end{array}$} \\
\hline & & & & & & Clinical & $X$-Ray & Clinical & $X$-Ray & & & & \\
\hline $\begin{array}{l}1 \\
2 \\
3 \\
4 \\
5\end{array}$ & $\begin{array}{l}\mathbf{F} \\
\mathbf{F} \\
\mathbf{F} \\
\mathbf{F} \\
\mathbf{F}\end{array}$ & $\begin{array}{l}51 \\
54 \\
44 \\
44 \\
54\end{array}$ & $\begin{array}{r}32 \\
20 \\
2 \\
5 \\
5\end{array}$ & $\begin{array}{l}\mathbf{0} \\
0 \\
0 \\
0 \\
0\end{array}$ & $\begin{array}{l}+ \\
++ \\
++ \\
++ \\
+\end{array}$ & $\begin{array}{l}\text { R.A. } \\
\text { R.A. } \\
\text { R.A. } \\
\text { R.A. } \\
\text { R.A. }\end{array}$ & $\begin{array}{l}\text { R.A. } \\
\text { R.A. } \\
\text { R.A. } \\
\text { R.A. } \\
\text { R.A. }\end{array}$ & $\begin{array}{c}\text { Cervical } \\
\text { nil } \\
\text { nil } \\
\text { nil } \\
\text { nil }\end{array}$ & $\begin{array}{l}\text { nil } \\
\text { nil } \\
\text { nil } \\
\text { nil } \\
\text { nil }\end{array}$ & $\begin{array}{l}+ \\
+ \\
+ \\
+ \\
+\end{array}$ & $\begin{array}{r}12 \\
8 \\
47 \\
6 \\
20\end{array}$ & $\begin{array}{r}50 \\
25 \\
50 \\
50 \\
100\end{array}$ & $\begin{array}{l}\text { Mitral } \\
\text { Mitral } \\
\text { Mitral } \\
\text { Mitral } \\
\text { Mitral, }\end{array}$ \\
\hline 6 & $\mathbf{F}$ & 70 & 20 & 0 & + & R.A. & R.A. & Cervical & nil & + & 83 & 50 & Mitral, \\
\hline $\begin{array}{l}7 \\
8\end{array}$ & $\begin{array}{l}\mathbf{F} \\
\mathbf{M}\end{array}$ & $\begin{array}{l}54 \\
39\end{array}$ & $\begin{array}{r}10 \\
5\end{array}$ & $\begin{array}{l}0 \\
1\end{array}$ & + & $\begin{array}{l}\text { R.A. } \\
\text { R.A. }\end{array}$ & $\begin{array}{l}\text { R.A. } \\
\text { R.A. }\end{array}$ & $\begin{array}{l}\text { Cervical } \\
\text { Cervical }\end{array}$ & $\begin{array}{l}\text { nil } \\
\text { nil }\end{array}$ & + & $\begin{array}{l}55 \\
27\end{array}$ & $\begin{array}{r}50 \\
1,600\end{array}$ & $\begin{array}{l}\text { Aortic } \\
\text { Mitral, } \\
\text { aortic }\end{array}$ \\
\hline $\begin{array}{r}9 \\
10 \\
11\end{array}$ & $\begin{array}{l}\mathbf{M} \\
\mathbf{M} \\
\mathbf{F}\end{array}$ & $\begin{array}{l}55 \\
53 \\
18\end{array}$ & $\begin{array}{r}3 \\
10 \\
6\end{array}$ & $\begin{array}{l}2 \\
1 \\
1\end{array}$ & $\begin{array}{l}++ \\
+t \\
+t\end{array}$ & $\begin{array}{l}\text { R.A. } \\
\text { R.A. } \\
\text { R.A. }\end{array}$ & $\begin{array}{l}\text { R.A. } \\
\text { R.A. } \\
\text { R.A. }\end{array}$ & $\begin{array}{c}\text { nil } \\
\text { Cervical } \\
\text { nil }\end{array}$ & $\begin{array}{l}\text { nil } \\
\text { nil } \\
\text { nil }\end{array}$ & $\begin{array}{l}+ \\
+ \\
+\end{array}$ & $\begin{array}{r}40 \\
3 \\
19\end{array}$ & $\begin{array}{r}100 \\
25 \\
150\end{array}$ & $\begin{array}{l}\text { Mitral } \\
\text { Mitral } \\
\text { Mitral, } \\
\text { aortic }\end{array}$ \\
\hline $\begin{array}{l}12 \\
13\end{array}$ & $\begin{array}{l}\mathbf{F} \\
\mathbf{F}\end{array}$ & $\begin{array}{l}45 \\
47\end{array}$ & $\begin{array}{c}3 \\
3 \\
\text { mths }\end{array}$ & $\begin{array}{l}1 \\
1\end{array}$ & + & $\begin{array}{l}\text { R.A. } \\
\text { R.A. }\end{array}$ & $\begin{array}{l}\text { nil } \\
\text { nil }\end{array}$ & $\begin{array}{l}\text { nil } \\
\text { nil }\end{array}$ & $\begin{array}{l}\text { nil } \\
\text { nil }\end{array}$ & - & $\begin{array}{l}10 \\
22\end{array}$ & $\begin{array}{l}150 \\
100\end{array}$ & $\begin{array}{l}\text { Mitral } \\
\text { Mitral }\end{array}$ \\
\hline 14 & $\mathbf{F}$ & 20 & 5 & 1 & $+t+$ & $\begin{array}{l}\text { Indeter- } \\
\text { minate }\end{array}$ & nil & nil & nil & - & 2 & 260 & Mitral \\
\hline 15 & $\mathbf{M}$ & 23 & 3 & 1 & ++ & nil & nil & $\begin{array}{c}\text { Lumbo- } \\
\text { dorsal }\end{array}$ & $\begin{array}{c}\text { Typical } \\
\text { spon- } \\
\text { dylitis } \\
\text { (Fig. 4) }\end{array}$ & - & 5 & 100 & Aortic \\
\hline 16 & $\mathbf{M}$ & 62 & 10 & 2 & $+t$ & nil & $\begin{array}{l}\text { Healed } \\
\text { osteo- } \\
\text { porosis }\end{array}$ & $\begin{array}{c}\text { Lumbo- } \\
\text { dorsal }\end{array}$ & $\begin{array}{l}\text { Spon- } \\
\text { dylitis }\end{array}$ & 一 & 47 & 50 & Mitral \\
\hline 17 & $\mathbf{M}$ & 47 & 4 & 0 & $+t+$ & nil & $\begin{array}{c}\text { wrists } \\
\text { nil }\end{array}$ & $\begin{array}{l}\text { Lumbo- } \\
\text { dorsal }\end{array}$ & $\begin{array}{l}\text { Spon- } \\
\text { dylitis }\end{array}$ & - & 42 & 100 & Mitral, \\
\hline 18 & $\mathbf{M}$ & 31 & 4 & 0 & $+t+$ & $\begin{array}{l}\text { Indeter- } \\
\text { minate }\end{array}$ & $\begin{array}{l}\text { Healed } \\
\text { osteo- } \\
\text { porosis } \\
\text { feet }\end{array}$ & $\begin{array}{c}\text { Lumbo- } \\
\text { dorsal }\end{array}$ & $\begin{array}{l}\text { Spon- } \\
\text { dylitis }\end{array}$ & - & 35 & 100 & $\begin{array}{l}\text { Mitral, } \\
\text { aortic }\end{array}$ \\
\hline 19 & $\mathbf{F}$ & 33 & 4 & 3 & ++ & R.A. & $\begin{array}{l}\text { Juxta } \\
\text { articular } \\
\text { porosis } \\
\text { only }\end{array}$ & nil & nil & - & 22 & 130 & $\begin{array}{l}\text { Mitral, } \\
\text { aortic }\end{array}$ \\
\hline 20 & $\mathbf{F}$ & 26 & 2 & 3 & $+t+$ & $\begin{array}{l}\text { Effusions } \\
\text { hyper- } \\
\text { mobility }\end{array}$ & nil & nil & nil & - & 20 & 150 & $\begin{array}{c}\text { Mitral, } \\
\text { aortic }\end{array}$ \\
\hline 21 & $\mathbf{F}$ & 46 & 18 & 3 & ++ & $\begin{array}{c}\text { Effusions } \\
\text { nodules }\end{array}$ & nil & nil & nil & - & 10 & 25 & Mitral \\
\hline 22 & M & 38 & 8 & 4 & +++ & $\begin{array}{l}\text { Effusions } \\
\text { only }\end{array}$ & nil & $\begin{array}{l}\text { Lumbo- } \\
\text { dorsal }\end{array}$ & $\begin{array}{l}\text { Spon- } \\
\text { dylitis }\end{array}$ & - & 50 & not done & $\begin{array}{l}\text { Mitral, } \\
\text { aortic }\end{array}$ \\
\hline 23 & $\mathbf{M}$ & 41 & 2 & 3 & +++ & $\begin{array}{l}\text { Stiff } \\
\text { shoulders }\end{array}$ & nil & $\begin{array}{l}\text { Lumbo- } \\
\text { dorsal }\end{array}$ & $\begin{array}{l}\text { Fused } \\
\text { sacro- } \\
\text { iliac } \\
\text { joints }\end{array}$ & - & 2 & not done & $\begin{array}{c}\text { Mitral, } \\
\text { aortic }\end{array}$ \\
\hline 24 & M & 48 & 9 & 4 & ++ & $\begin{array}{l}\text { Stiff } \\
\text { shoulders }\end{array}$ & nil & $\begin{array}{c}\text { Lumbo- } \\
\text { dorsal }\end{array}$ & $\begin{array}{l}\text { Spon- } \\
\text { dylitis }\end{array}$ & - & 18 & 130 & Aortic \\
\hline 25 & M & 42 & 16 & 5 & $+t+$ & nil & nil & $\begin{array}{l}\text { Lumbo- } \\
\text { dorsal }\end{array}$ & $\begin{array}{l}\text { Spon- } \\
\text { dylitis }\end{array}$ & - & 10 & 130 & $\begin{array}{c}\text { Mitral, } \\
\text { aortic }\end{array}$ \\
\hline 26 & $\mathbf{M}$ & 29 & 10 & 5 & $++t$ & $\begin{array}{l}\text { Hyper- } \\
\text { mobility }\end{array}$ & nil & $\begin{array}{l}\text { Lumbo- } \\
\text { dorsal }\end{array}$ & $\begin{array}{l}\text { Spon- } \\
\text { dylitis }\end{array}$ & - & 1 & 100 & $\begin{array}{l}\text { Mitral, } \\
\text { aortic }\end{array}$ \\
\hline 27 & $\mathbf{M}$ & 35 & 20 & 6 & $+t+$ & $\begin{array}{l}\text { Hyper- } \\
\text { mobility } \\
\text { Effusions } \\
\text { Nodules }\end{array}$ & $\begin{array}{l}\text { Osteo- } \\
\text { porosis } \\
\text { (Fig. 1b) }\end{array}$ & $\begin{array}{l}\text { Whole } \\
\text { spine }\end{array}$ & $\begin{array}{l}\text { Spon- } \\
\text { dylitis } \\
\text { (Figs. 1 } a \text {, } \\
2,3 \text { ) }\end{array}$ & - & 40 & 1,100 & $\begin{array}{c}\text { Mitral, } \\
\text { aortic }\end{array}$ \\
\hline 28 & $\mathbf{F}$ & 39 & 20 & 3 & $+t+$ & $\begin{array}{l}\text { Hyper- } \\
\text { mobility }\end{array}$ & nil & $\begin{array}{l}\text { Whole } \\
\text { spine }\end{array}$ & $\begin{array}{l}\text { Spon- } \\
\text { dylitis }\end{array}$ & - & 25 & 100 & Mitral \\
\hline 29 & $\mathbf{F}$ & 25 & 15 & 5 & $+t+$ & $\begin{array}{l}\text { Hyper- } \\
\text { mobility } \\
\text { Nodules }\end{array}$ & $\begin{array}{l}\text { Osteo- } \\
\text { porosis }\end{array}$ & $\begin{array}{c}\text { Lumbo- } \\
\text { dorsal }\end{array}$ & $\begin{array}{l}\text { Erosions } \\
\text { sacro- } \\
\text { iliac } \\
\text { joints }\end{array}$ & - & 40 & 800 & $\begin{array}{l}\text { Mitral, } \\
\text { aortic }\end{array}$ \\
\hline
\end{tabular}

symptoms in no way comparable to the striking effect obtained in rheumatic fever. Spinal arthritis was limited to the cervical region and in most cases there were confirmatory radiographical changes in the hands and feet consisting of juxta-articular osteoporosis and erosions. All, with one exception, were considered to have involvement of the mitral valve. The exception, a woman aged 54, did not give any previous history of rheumatic fever or symptoms which could be ascribed to a cardiovascular disorder. Her severe destructive rheumatoid arthritis of 10 years' duration had confined her 

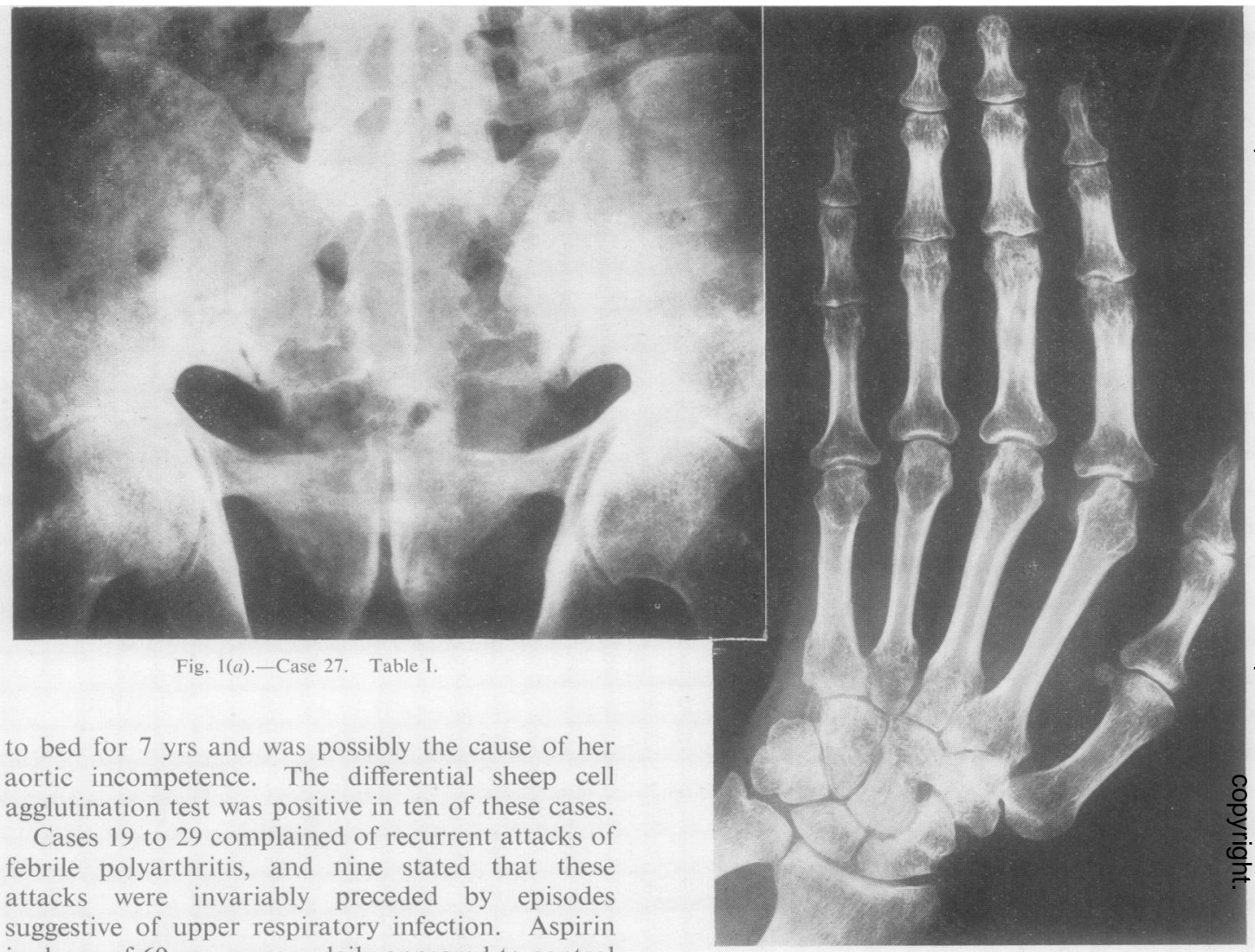

to bed for 7 yrs and was possibly the cause of her aortic incompetence. The differential sheep cell agglutination test was positive in ten of these cases.

Cases 19 to 29 complained of recurrent attacks of febrile polyarthritis, and nine stated that these attacks were invariably preceded by episodes suggestive of upper respiratory infection. Aspirin in doses of $60 \mathrm{gr}$. or more daily appeared to control joint pains and fever when present, though in patients with ankylosed spines mobility was naturally not restored. Thus the therapeutic response was of the order one would expect in patients with rheumatic fever.

Ten of these patients showed changes in the peripheral joints, but in only one could these be described as typical of rheumatoid arthritis. Two displayed moderate limitation of movement in the shoulders only. Hypermobility, particularly of the metacarpophalangeal joints of the hands, was found in Case 20 and Cases 26-29: it arose from laxity of the ligaments and capsules which permitted a considerable degree of ulnar deviation, but no actual dislocations (Fig. 1b).

Additional findings included effusions into the metacarpophalangeal joints and extensor tendon sheaths at the wrists and tendon nodules, which in one case had produced bilateral compressions of the median nerves in the carpal tunnels (Case 21).

In eight of the patients in this group there was gross limitation of movement of the lumbodorsal spine (Cases 22-29 inclusive), and in two of them the

whole spine was virtually ankylosed. Three patient $\stackrel{3}{3}$ had deep $x$-ray therapy applied to the spine, but in no case was this followed by any symptomatic improvement.

The $x$ rays of the hands and feet in these patientso did not reveal any erosions of the rheumatoid type $\frac{0}{3}$ In one patient (Case 19) there was juxta-articular. porosis only, and Cases 27 and 29 showed in addition을 a curious alteration of the bone trabecular pattern (Fig. $1 b$ ). $X$ rays of the sacro-iliac joints showe $\frac{\text { o }}{2}$ complete fusion in one patient. In seven there wer abnormalities unlike those usually seen in anky losing spondylitis consisting of very small erosions surrounded by spotty areas of sclerosis (Fig. 1a) The radiological changes in their spines consisted of irregularity and fusion of the interfacetal joints, $\mathbf{\omega}$ narrowing of the intervertebral discs, increase height of the vertebral bodies, and some ossificatiore in the discs; appearances which are unlike those o $\mathbb{\varnothing}$ typical ankylosing spondylitis (Figs 2 and 3).

Isolated aortic valve disease was encountered i 


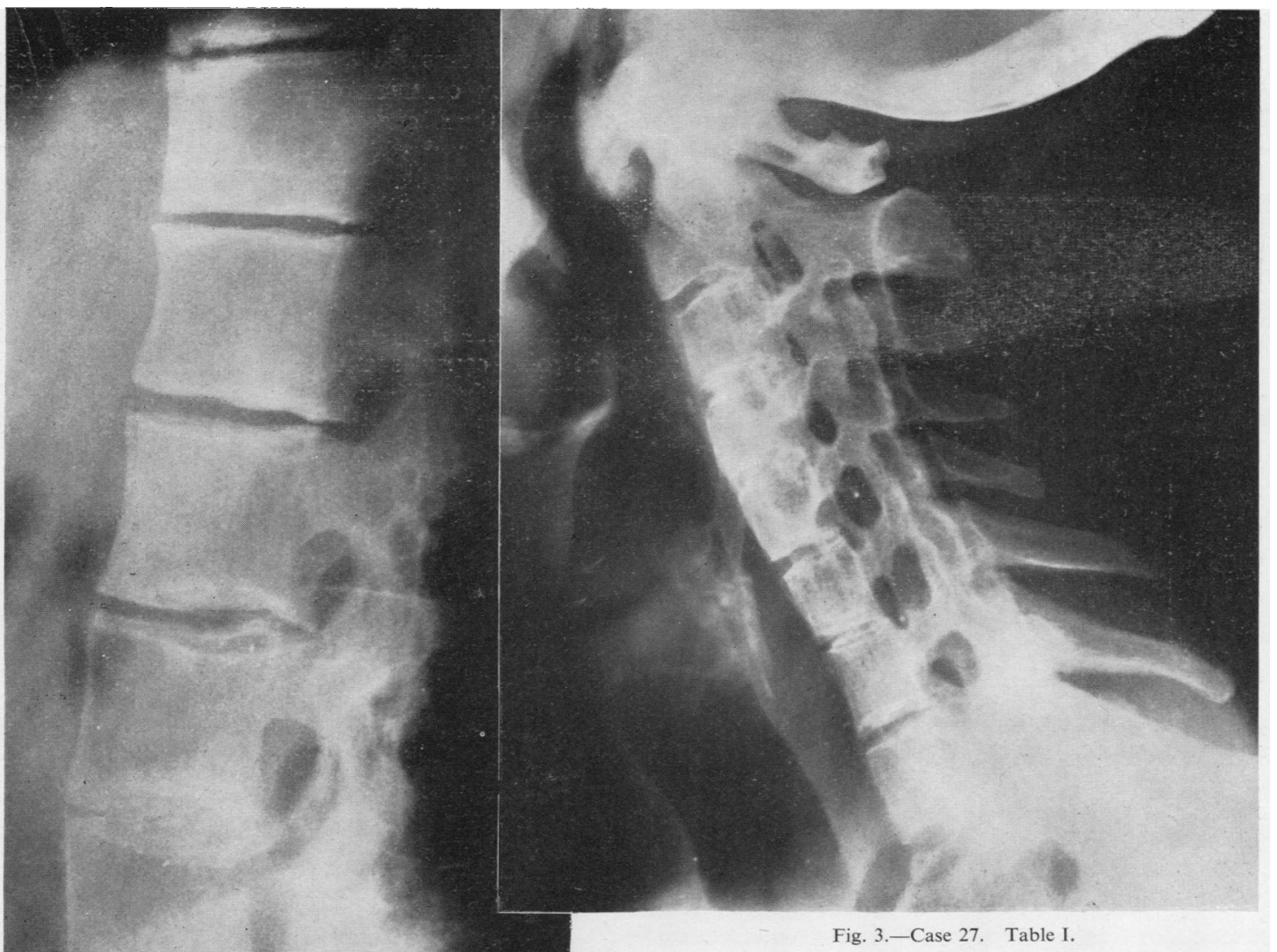

Case 14.- A girl aged 20 developed mitral stenosis after an attack of rheumatic fever when she was 16 , which was preceded for twelve months by arthritis of the Fig. 2.-Case 27. Table I. hands and feet. The polyarthritis was not progressing at the time of examination and the joint changes were indeterminate in nature, comprising soft tissue thickening of the ankles only.

Case 15.-A man aged 23 was considered to have inactive ankylosing spondylitis. The $x$-ray appearances of his sacro-iliac joints-big erosions and large fluffy areas of sclerosis-were typical (Fig. 4, overleaf). He had derived great benefit from radiotherapy. His isolated aortic lesion was regarded as rheumatic in origin in view of his previous history of rheumatic fever.

Case 16.-A man aged 62 who, 10 years after a second attack of rheumatic fever, developed progressive stiffness of the lumbodorsal spine. Radiographs of the sacroiliac joints disclosed changes similar to those described above in the patients with recurrent rheumatic fever. $\mathrm{He}$ also responded to radiotherapy.

Cases 17 and 18.-These differed from the patients with recurrent rheumatic fever and stiffness of the lumbodorsal spine only by the absence of a history of repeated attacks. 


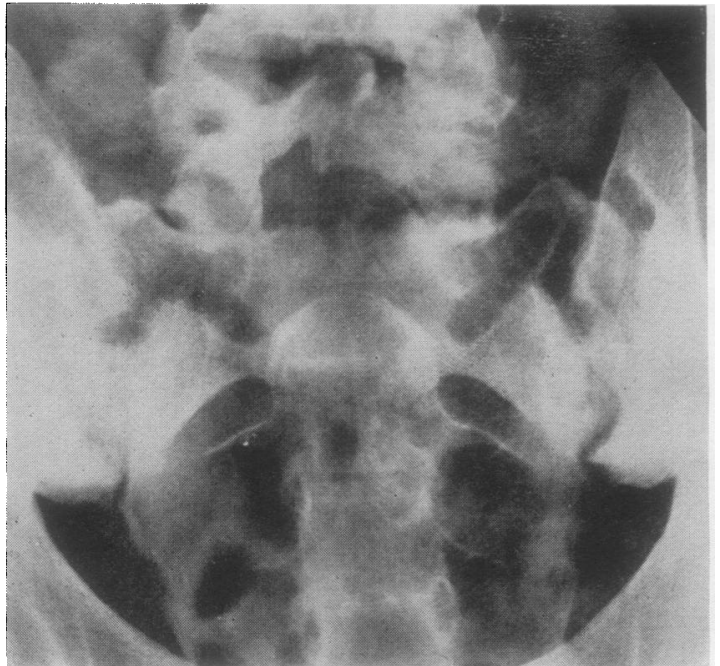

Fig. 4.-Case 15 Table I.

Table II (opposite) contains details from the case notes of the 26 patients who did not attend for re-examination. Cases 1-6 inclusive were thought to have rheumatoid arthritis; excepting Case 6 with congenital pulmonary stenosis, their valve lesions were considered to be rheumatic in origin.

Case 7 had, for a number of years, complained of attacks described as "asthma". During the course of her illness she developed an arthritis of the rheumatoid type, arteritis of the digital arteries, and aortic incompetence. She was considered on clinical grounds to have periarteritis nodosa.

Frequent bouts of iritis after urethritis during the first world war preceded the polyarthritis in Case 11 who was thought to have Reiter's disease. The aetiology of his aortic incompetence was never established.

The remaining patients were all suffering from rheumatic heart disease, and seven of them (Cases 20-26) displayed joint changes of the type previously described as possibly due to the rheumatic process. Limitation of movement in the lumbodorsal spine was a feature in three of these patients of whom two showed accompanying changes in the peripheral joints.

Valvular heart disease was encountered in nineteen of 1,562 patients $(1 \cdot 2$ per cent.) with rheumatoid arthritis seen during the 5-year period of the survey. In sixteen ( 1 per cent.), the valvular lesions were of rheumatic origin, a smaller clinical incidence than the 4 per cent. reported by Sokoloff (1953).

490 patients with spondylitis were seen during the same period and sixteen of these had valve lesions $(3 \cdot 3$ per cent.), of which fifteen ( $3 \cdot 1$ per cent.) were rheumatic. Bernstein and Broch (1949) encountered rheumatic heart disease in 2.8 per cent. of their 352 cases of ankylosing spondylitis.

\section{Discussion}

Both rheumatoid arthritis and rheumatic heart disease are common conditions. The association between them encountered in this study is not $\overrightarrow{\vec{\rho}}$ unexpected and probably represents no more than ao chance occurrence of two diseases in the sameo patient.

Joint changes seen in the patients who had suffered $\vec{ه}$ repeated attacks of rheumatic fever were similar in many respects to those described by Jaccoud (1869), but in a lesser degree, the lesions being confined to. the joint capsules and tendons. It was in these $\overrightarrow{-}$ structures that Klinge (1933) found the most marked histological changes in a patient dying of rheumation fever.

A number of patients in the series were drawn $\vec{\perp}$ from a clinic for the diagnosis of ankylosing spon- $\omega$ dylitis, a fact which may account for the high incidence of spinal involvement. There seemed, however, to be certain differences between these ${ }_{-}$ patients and typical cases of ankylosing spondylitis, $(s)$ notably the history of repeated attacks of rheumatic fever, absence of focal points, presence of tendon nodules, and differing radiographic changes in the sacro-iliac joints. Furthermore, in five cases, the spondylitis was associated with peripheral jo $t_{0}$ changes of the Jaccoud type (Table I, Cases 26 to $99 \mathrm{G}$ inclusive; Table II, Case 24).

Recurrent attacks of rheumatic fever continuithgo into adult life are distinctly uncommon, and the cases reported in this paper represent the onlyo patients seen in this clinic in whom this diagnosiso has been considered likely. Although the evidence is incomplete in that we have no bacteriologicalo proof of preceding streptococcal infection (except ${ }^{3}$ in Case 27, Table I), and the Antistreptolysin Titrations are also unhelpful, the frequent history of preceding infection, the striking response to salicylates, and the curious nature of the joint $t_{-}^{\circ}$ lesions, suggest that at least seventeen of these? patients were, in fact, suffering from recurrento rheumatic fever. It is interesting that the hearts disease in these seventeen patients tended to be more severe and progressive than in the series as a whole?

If we accept the view that these patients areo suffering from recurrent rheumatic fever, it raises the possibility that their joint lesions may be due to thes rheumatic fever process. Alternatively, some of these patients might be suffering from a recurrent, acute febrile form of ankylosing spondylitis with ${ }^{\omega}$ cardiac involvement or simply a coincident anky losing spondylitis and recurrent rheumatic fever Further resolution of this problem must awaite bacteriological and serological studies of this type of case during the acute episodes, but for the moment 
TABLE II

FINDINGS IN 26 PATIENTS

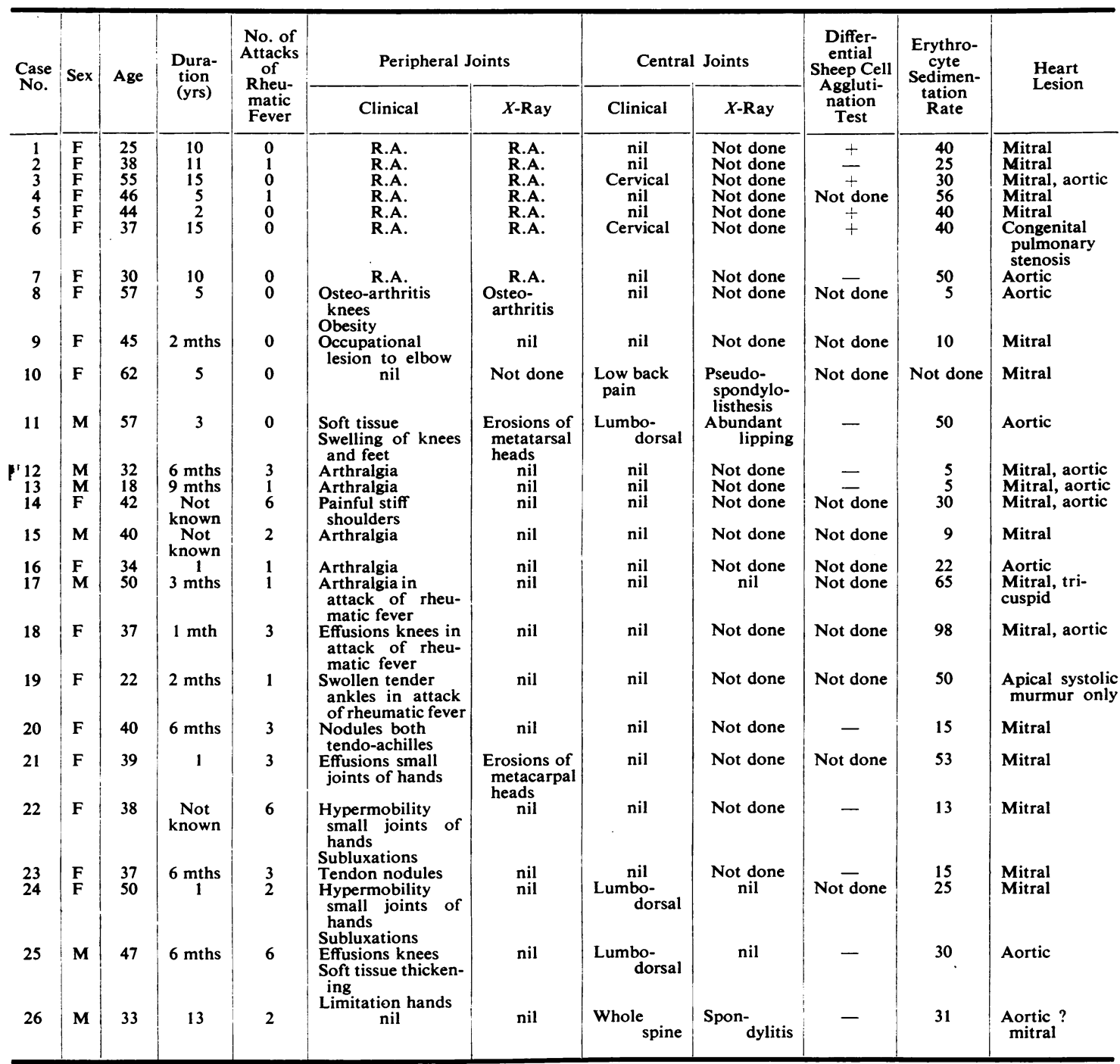

the practical management appears to be that of recurrent rheumatic fever.

\section{Summary}

(1) Clinical, radiological, and serological data from a group of patients with chronic arthritis and rheumatic heart disease were analysed.

(2) An expected association between rheumatoid arthritis and rheumatic heart disease was encountered.

(3) A group of patients with recurrent febrile polyarthritic episodes, valvular heart disease, atypi- cal spondylitis, and peripheral joint changes of the Jaccoud type is described.

(4) In this group the attacks of polyarthritis were often preceded by upper respiratory infection and salicylate therapy provided a most effective method of controlling the symptoms.

(5) The significance of these findings is discussed.

I am indebted to Prof. J. H. Kellgren for his help and encouragement in the preparation of this paper. Thanks are also due to Prof. H. B. Maitland who provided facilities for the carrying out of antistreptolysin titrations, and to the Department of Medical Illustration, Manchester Royal Infirmary, for the $x$-ray reproductions. 


\section{REFERENCES}

Arnsø, E., Brøchner-Mortensen, K., and Hastrup, B. (1951). Acta med. scand., 141, 77.

Ball, J. (1950). Lancet, 2, 520.

Bauer, W., Clark, W. S., and Kulka, J. P. (1951). Proceedings of American Rheumatism Association Annual Meeting. Annals of the Rheumatic Diseases, 10, 470

Bernstein, L., and Broch, O. J. (1949). Acta med. scand., 135, 185

Bywaters, E. G. L. (1950). Brit. Heart J., 12, 101.

Cabot, R. C. (1926). "Facts on the Heart." Saunders, Philadelphia.

Coburn, A. F., and Pauli, R. H. (1935). J. clin. Invest., 14, 755.

Coombs, C. F. (1924). "Rheumatic Heart Disease." Wright, Bristol.

Edström, G. (1935). "Febris Rheumatica." Berlingska, Lund

(1940). Acta med. scand., 104, 396.

Ehlertsen, C. F. (1942). Ibid., $112,353$.

Engleman, E. P., Hollister, L., and Kolb, F. (1951). Abs. Annals of the Rheumatic Diseases, 10, 492 .

Fletcher, D. E., and Rowley, K. A. (1952). Brit. J. Radiol., 25, 282.

Hart, F. D., Robinson, K. C., Allchin, F. M., and Maclagan, N.F. (1949). Quart. J. Med., 18, 217.

Herrick, W. W., and Tyson, T. L. (1941). Ann. intern. Med., 15, 994.

Jaccoud, S. (1869). "Leçons de Clinique Médical faites à l'Hôpital de la Charitè", 2nd ed. Delahaye, Paris.

Jespersen, K. (1941). Z. Rheumaforsch., 4, 108.

Klinge, F. (1933). Ergebn. allg. Path. path. anat., 27, 154.

Krebs, W., and Wurm, H. (1938). "Die Bechterewsche Krankheit." Steinkopff, Dresden.

Mowbray, R., Latner, A. L., and Middlemiss, J. H. (1949). Quart. J. Med., 18, 187.

Parkinson, J., and Hartley, R. (1946). Brit. Heart J., 8, 212.

Poynton, F. J., and Paine, A. (1913). "Researches on Rheumatism." Churchill, London.

Rose, H. M., Ragan, C., Pearce, E., and Lipman, M. O. (1948). Proc. Soc. exp. Biol. (N.Y.), 68, 1.

Rothbard, S., Watson, R. F., Swift, H. F., and Wilson, A. T. (1948). Arch. intern. Med., 82, 229.

Sharp, J., and Easson, E. C. (1954). Brit. med. J., 1, 619.

Sokoloff, L. (1953). Amer. Heart J., 45, 635.

Swift, H. F. (1952). In "Rheumatic Diseases." Proc. 7th int. Congr. rheum. Dis. American Rheumatism Association. Saunders, Philadelphia.

Todd, E. W. (1932). Brit. J. exp. Path., 13, 248.

Young, D., and Schwedel, J. B. (1944). Amer. Heart J., 28, 1.
L'arthrite chronique après le rheumatisme articulaire aigư

RÉSUMÉ

(1) On analysa les données cliniques, radiologiques et de laboratoire chez un groupe de malades atteints: d'arthrite chronique et de maladie de Bouillaud.

(2) Comme on s'y attendit, on trouva un rapport entre l'arthrite rhumatismale et la maladie de Bouillaud.

(3) On décrit un groupe de malades manifestant des음 épisodes polyarthritiques fébriles, une atteinte valvulaire du coeur, une spondylarthrite atypique et des尺्D altérations articulaires périphériques de type Jaccoud.

(4) Dans ce groupe les poussées articulaires furentes souvent précédées d'infections des voies respiratoiressupérieures et la thérapie salicylée s'avera la plus efficace pour obtenir un soulagement symptomatique.

(5) On discute la portée de ces résultats.

\section{La artritis crônica después del reumatismo poliarticular agudo \\ Sumario}

(1) Se analizaron los datos clínícos, radiológicos serológicos en un grupo de enfermos con artritis crónicâs y con reumatismo poliarticular agudo.

(2) Se encontró la anticipada asociación entre laf artritis reumatoide y el reumatismo poliarticular agudos-

(3) Se describe un grupo de enfermos manifestandos episodios poliartríticos febriles, una enfermedad valvularD del corazón, una espondilartritis atípica y alteracione $\mathcal{D}_{\mathbb{D}}$ articulares periféricas de tipo de Jaccoud.

(4) En este grupo ataques articulares fueron a menudळ precedidos de infecciones de las vías respiratorias superiores y la terapia salicilada se mostró la más efigaz para controlar los síntomas.

(5) Se discute el significado de estos datos. 